\title{
African Music and the Search for a New Musical Paradigm: A Study of Ikorodo Dance Group of Orba Enugu State, Nigeria
}

\author{
Orajaka Sussan Nwakego, Emmanuel Umezinwa \\ Institute of African Studies, University of Nigeria, Nsukka, Nigeria \\ Email: orajakalinus@gmail.com, emma2000@yahoo.com
}

Received 26 February 2015; accepted 16 March 2015; published 18 March 2015

Copyright @ 2015 by authors and Scientific Research Publishing Inc.

This work is licensed under the Creative Commons Attribution International License (CC BY). http://creativecommons.org/licenses/by/4.0/

(c) (i) Open Access

\begin{abstract}
Africa's search for a new paradigm for sustainable development can only be complemented by the search for new musical paradigm that will change the way Africa notates and intones its musical performance. That search has made a study of the Ikorodo musical genre a compelling subject of research by this author. The study will expose new forms of notation, rhythm and dance that confirms the fact that it is difficult to notate the African music genre in accordance with Western system of notation. The pitches and staff difference in intonation is not easily translated. The rhythmic aspects of African music such as Ikorodo unite the music of various groups and areas into discernable rythm. Rhythm is made of patterns, similar patterns are found throughout Africa.
\end{abstract}

\section{Keywords}

Philosophy, African Music, Paradigm, Ikorodo Dance

\section{Introduction}

In traditional Africa, music is an integral part of life and is linked with the world view of the society in which it is produced. Africa is a continent where a rich and diverse cultural heritage exists. Hundreds of different languages are spoken in Africa. Much of traditional Africa music does not have a written tradition. This makes it difficult to notate the music on paper using western system of notation. The pitches and staff difference in intonation is not easily translated. The rhythmic aspects of African music unite the music of various groups and areas. Rhythm is made of patterns, similar patterns are found throughout Africa. Harmonization is typically created through singling in thirds, fourths, fifth, parallel to the main melody. Since primordial times, men have sung and played music, it was found in temples, homes, and social gathering, and music was regarded as the 
language of the gods and was therefore held sacred (Frederic Fay and Willard I. Musser, 1960). There were musical instruments, pictures and writing which will tell stories about music which can be found in museums. Even from the records of the Bible, we are able to learn a great deal about music of the Hebrew people. King David, himself was a musician. There were persists who blew trumpets, played cymbals and harps and at the same time sang praises to God. As with art and sculpture, music began in a primitive way by using improvisations. It is significant that every country has and loves music.

Nigeria as a nation, is such a diversified country both physical and culturally, that it would take no great genius to see that the music of the country must also be very versatile in nature. It is a well known fact that musically speaking Nigeria is more participatory nation than a listening one (Peggy, 1962). This means that the Nigerian audiences usually join in performance and enjoy music. This is seen when the village band starts performances, villagers sit around for only a short time, after that, join either in nodding their heads, or participate even if is only by clapping their hands and cheering. The Igbo music is known for its wide range of sounds, tempos and pitches making it quite easy to be incorporated into daily life.

The music relies on percussion instrument (idiophones), (aero phone), (flute and horn), chordophone (ubo-aka, une) and membranophone (drum, Igba). The drums hold a very respected place among all Nigerian music, especially in Igbo music where it is the most important instrument. The Udo is a bell shaped drum (pot) that changes pitches when water is added inside the pot, since there is no cover for its opening. The Igba drum creates a sound similar to the native language thus doodling the talking drum; it is played in a more complicated manner where the pitch varies depending on how tightly its cover is and where the musician stops the vibration. The Ekwe holds a more useful purpose than just music. Is the Ekwe used to signal emergency, warm villagers about the presence to summon council meeting but town criers. Those instruments in the communities are played by striking a stick or hand straight across the opening along with the various drums, gongs are also played. These are useful during dancing because they help the dancers keep time and tempo. Along with these two important instruments are also a woodblock, a wood wind similar to a flute and basket rattles. Igbo music has remained very traditional while at the same time remaining relatively open to modernization and fusion with the newer style.

\section{History, Philosophy and Description of Ikorodo Orba Cultural Group}

Having described in general terms the background of Africa traditional music. The researcher would focus on the Ikorodo Orba cultural dance in Enugu state of Nigeria. Orba is an autonomous community in Udenu local Government Area of Nsukka. Orba as a community is noted for their merchandise-as the highest commercial community in this area as they are known for their commercial ventures. Orba is sited and famously noted for their Orie Orba market which attracts traders from many parts of Nigerai who engage in buying and selling of goods.

However, a section of the community called Owere-Eze Orba, in may 2005 decided to embark on cultural socialization of the town by establishing the "new famous Ikorodo Orba cultural dance being played all over the country". This cultural dance has embraced both socail and political life of the people. According to their secretary Mr. Eze Kelvin (2012) "the name of Igwe of Orba is (HRH Igwe Simon Onah)."

Ikorodo Orba dance has been in existence for long time now in Orba community. It came from the Igara in Idah of Benue state. The Ikorodo Orba dance chairman is Mr. Augustin Attamah. There is a call and response mode in greeting by the Ikorodo Orba troupe. The call is Orba group eee... and the response is "Udo Diri Umu-uwa”. In Nsukka Local Government Area, Igbo-Nsukka is divided into three (3) major parts from which music came.

1) Orba downwards towards Nsukka came from Igala, in Kogi state.

2) Imilike upwards came from Idioma in Benue state.

3) Ukehe came from Umuojebo Ogene in Enugu state. The Ikorodo Orba group narrated that this music is played during moonlight games, weddings-anniversaries, naming ceremonies, Burial ceremonies, Offala festivals, chieftaincy title taking; they use the music for relaxation after farm work. They are all Christians. There is no taboo or incantation attached to the music. They select only young girls who are their children by birth. There are no married women among them, but any place they perform or play their music married women can dance and enjoy their music. Once young girls in the troop were fifty in number but they all got married because the music expose them to a social setting where their good qualities were portrayed to the society. The Ikorodo Orba in Udenu Local Government Area in the Igbo Nsukka cultural environment is musical, ceremonious and recrea- 
tional.

Igbo land is full of festivities which draw people out doors in excitement for all the calendar months of the year. In Igbo land, there are also feast such as cultural wedding ceremonies (Igba-Nkwu), child birth (Omugwo) naming and burial (Nkwam-Ozu) ceremonies, celebration of membership into age grade, Ikorodo Orba participate in all of the events. The cultural activities are supported with cultural music, dances and masquerade. The Ikorodo Orba music is melodious, meaningful and carries a lot of messages. They are also composed to reflect actual situations, events and to honour heroes and discourage vices. Their dances are pleasant, graceful and they torch the mind as well as inspire courtship. The dances have names that identified with particular communities and it is not limited. The dances and masquerades are performed freely for everybody with no exception and not for a particular class. The costumes are artistic and of various types to reflect the particular dance. The dancers are of different ages - the school age, the youth and adults, with wives and kids. They are adorable in their costumes. The Ikorodo Orba groups wear different forms of cloths with red cap and beads that signified titled men and with different types of costumes and sizes sculptured out of wood. They go for federal, state or local exhibitions anytime and anywhere. Our traditional musical instruments are simple forms realized from natural elements. This reinforces the fact that the traditional-Igbo understand that nature is musical.

The instrument are artistic and it includes wooden-sticks, Ekwe, Oja, Igba, Oyo/Osha, and Opi and also the metal gong (Ogene) this is in Igbo Origin, reflect to Igbo technology as old as the Iron age. The musical instrument used by Ikorodo music involves series of horns:

$1^{\text {st }}$ horn is for melody and rhythm.

$2^{\text {nd }}$ horn is for harmony.

$3^{\text {rd }}$ horn is for leading the vocalist who is the leader.

$4^{\text {th }}$ horn is for bass and balancing the sound of the music.

The musical instruments used by Ikorodo Orba group are namely:

1) Long drum - Igba (membranophone).

2) Metal gong-Ogene (idiophone) medium size.

3) Four horns—4 Opi (aero phone) in different sizes.

4) Small slit drum-Ekwe (idiophone family).

5) Basket rattles- two Oyo/Osha (idiophone family).

All these are for melody and it helps in curing H.B.P and makes them happy in any given environment (Ekwerou, B.C., 2003: pp. 340-357).

In the primitive stage, the indigenous instruments were made; to find any of these musical instruments today is a major task, since it is not ready available. Many of these musical instruments are now reproduced by the blacksmith either by wooden form or metal form.

Ikorodo Orba is a musical type which makes use of a number of stylistic variations. It has a non-stanza declamatory style which may be used according to the kind of statement, the Ikorodo vocalists as who is the leader of music makes wishes or according to his emotional frame of mind at any given moment. The group is on their $4^{\text {th }}$ group, selection of members are based on title married men and not single men why because they don't take single men is to avoid corruption of their youngsters dancing. The selection is also based on only title men by Orba origin.

According to Chief Jude Ossai (2007), Friday $7^{\text {th }}$ Sept 2007 was like any other day to many people but to the indigenes of Enugu state, it was day set aside for the celebration of new yam festival; the performance took place at Michael Opkara square Enugu where Ikorodo Orba was invited for a competition. This was first cultural festival to be organized by Sullivan Chime the Governor of Enugu state. The organizer of the festival was the department of culture and tourism under ministry of information of culture, headed by Chief Ferdinand Anikwe, a director in the unit.

The event took off at about 11:00 am with the arrival of many cultural troupes and masquerades from the government areas and development centers in the state. First to dance was the Ikorodo Orba cultural group from Udenu Local Government Area in Nsukka of Enugu North senatorial zone. The dancers, mainly females below the age of twenty (20), thrilled the audience with their body movement and artistry. It was a good and pleasant event for the people who had come to en-mass to watch the revival of their culture (Celebration, Chime, 2007).

\section{Conceptualizing Dance in Meaning and Value-Ikorodo as Dance}

In dance, dancing requires the movement of various body parties in time with rhythms (Mosunmola Omibiyi, 
1977). Dance can be defined as follows:

1) Dance is a process of moving rhythmically to music.

2) Dance is a move in a quick and lively manner.

3) Dance is series of steps, variations and movements tuned to music.

4) Dance is a social gathering at which people love to dance.

5) A series of movement that match the speed and rhythm of a piece of music.

A singing technique called and response is evident in Africa vocal music. There is a dux and a comes, that is a person leads the singing a phrase which is then answered by a group of singers. This technique is still very much used in today's music. Dance requires the various body p [arts in time to the rhythm. Africa dance is as varied in style and function as Africa music. Dancing is associated with both sacred and secular events and it plays a crucial role in education, work, entertainment, politics and ritual. Common African dance patterns include team dances using formalized patterns, such as straight lines or circular formatives, group dances that allow individuals to emerge and display their skills and solo dances, often performed by a powerful individual or professional entertainer. Bodily postures vary from the upright stance widely associated with political and ritual authority to the earth oriented movements, common in inclines the torso forward from the lips. Some maintain an upright posture and perform high starring movements.

\section{Some of the Identified Philosophical Lyrics and Instruments of Ikorodo as African Cultural Music}

The Ikorodo music uses fives traditional musical instruments in their dance. These include a pair of basket rattles (Osha), wooden palm gong (Ekwe), a long metal gong (Oro), four wooden Horn (Opi) with different names and pitches including, Isi-Opi (lead Horn) Mgbe, Apka and Una, and then two drums (Oke and Ada Igba). The music can be started with the "Igba" (drum) or Ekwe (wooden slit drum). These five come only for academic mention but we will go into details concerning the costumes and the paraphernalia.

\subsection{Costumes of Ikorodo}

For the men they put on white lace upon black trousers with a purple coloured and designed judge materials wrapped round their waist. They also put on red traditional cap with beads on their necks showing titled men of the town. For the ladies (dancers) they put on special skirt and blouse (top) with waist beads (Jigida) round their waists, leg rattles and beads (Aka) on their necks, see details in the attached photographs on instruments and costumes.

\subsection{Lyrics That Make Ikorodo an African Musical Model}

The musical lyrics of Ikorodo Orba traditional dance is amply recorded in their musical videos, radio programs and documentary productions. They project the values of African musical rhythm and notations. The lyrics are reflected in the books and journals of the Institute of African studies at the University of Nigeria. The lyrics contain five tracked songs and danced music as having acquired the philosophical values given in their interpretation below:

1) Ndi Nwobodo-means those who own the land.

2) Ogidigba-is a nonsense syllabus.

3) Ije Ogwube-means walk of a camelon.

4) Onye Emechari-means one who could not finish his assignment.

5) Apkupko Agu—means, lying on dried lion's skin. Only the first tracked vocal and instrument rhythms are analyzed on the music manuscript below. Also the picture of the group is shown as the group is performing with the researcher.

\subsection{Importance of Ikorodo Music}

The Ikorodo and their wooden drums and their appearances are the symbolic of Igbo's traditional music. They come in various sizes to reflect in the function, the community drums come in scales that reflect the level of use either at the kindred, village or community level to summon people during social gatherings (see Figure 1 and Figure 2). 


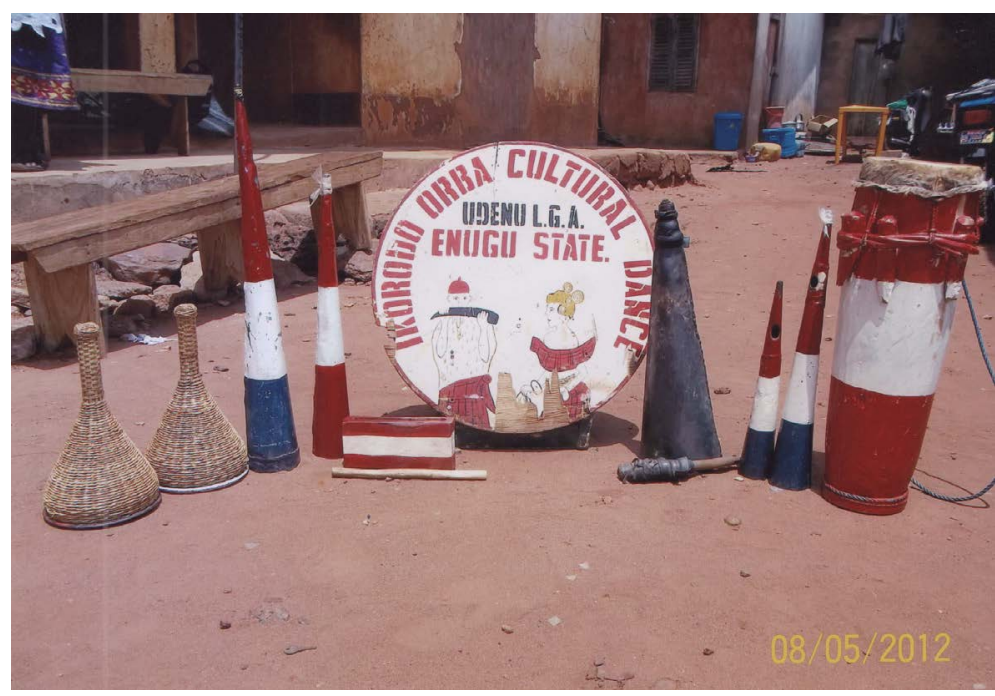

Figure 1. An assemble of compete Ikorodo music instruments-musical instruments of the powerful in Wawaland.

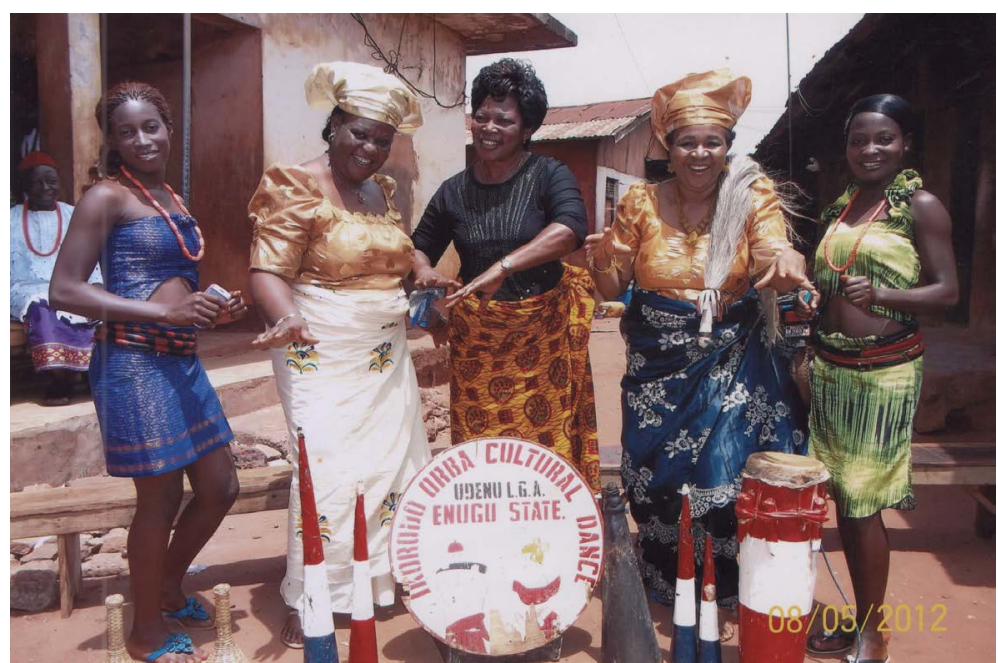

Figure 2. Orajaka-one of the authors and an Ikorodo Music Mother with the horse whip-tail over her shoulders.

Musical instruments in foreign countries or museums are the culture of the people (WWC Echezona, 1965). Ikorodo songs and music change the spirit of the Igbo-man hence working and singing kin complimentary. All these are aspects of our culture that create moments of joy, excitement and emotional feeling which cannot be measured.

Music has been used variously be different peoples. To some peoples, music is magic as it is often to get a prophet "into the mood" to prophesy. Music is sung as a lenient for the dead. Music is used to celebrate great victory. In Christendom, music is used to "call upon God". Music is also used for feasts and festival as well as in other social ceremonies. Generally, music plays a major role in the life of every individual, in terms of entertainment, relief, education and information.

\subsection{Analysis Discussion and Findings-Interpreting the Philosophy of Ikorodo}

Generally, the form of cantor's part requires a lot of improvisation and that is why the Ikorodo Orba, vocalist is a good singer. Their music is predominantly antiphonal that is solo and chorus alternates. Melodic phrases tend to be stepwise and in a descending progression. Stepwise and fall within the musical phrases is generally noticed 
more especially in all the songs. The wordings or text of the songs are usually very few and the same melody being repeated with crossing of parts, counter points and imitations with sequences. Another song form which is prominent among the Ikorodo group is what might be called their preludes and song.

\subsubsection{Vocal Techniques}

As you can see in the Ikorodo music 1, 2, 3, 4 and 5 the decoration of the melody with acciaccatura, the slur, ties, vibrato, and portamento. And appoggiatura (as shown in Ikorodo music Table 1). In the songs, the singer begins with the instruments starting in a regular pattern of $2_{4}$ and $4_{4}$ the first of which marks the position of the initial strong metrical accent.

\subsubsection{Scales}

The Ikorodo Orba music 1 is built on six notes. Usually CBAFEGC so it is sexatonic, in music II is built on " 5 " five notes usually BGCAE which is pentatonic. Music III is built on "7" seven notes, on BAGEFDC which is Heptatonic. Music iv and v are built on "7" seven notes usually on BAGBEF which is Heptatonic.

\subsubsection{Meters}

In these example the regular rhythm is in duple meter but the gong and drum rhythm are used and played with a combination of triple and duple meters in some of the songs in short there is a clash or per cussed suspension of triple and duple meters which resolve into a duple meters in songs 1 and 5. Durational values are arranged in configurations.

An example of these is the rhythm motif consisting of two or three units. These are long and short and unitary motifs see above chart.

\subsubsection{Incidental Harmony}

This occurs when the solo part and the chorus overlap in the song 1 bar 10 where there is a kind of hemiola. In case of musical instruments and chorus where the song keeps the time line that is an ostinato rhythm. There is kind of hemiola between the call and response in song 1, Ekwe, and Igba, and there is also a harmony between the instrument and the melody lines with the horns.

\subsubsection{Cross Rhythm}

Is another important feature but it is as more common with instruments than with voices and song keeping Ositato rhythm or inter locking of melodic shape.

\begin{tabular}{|c|c|c|c|c|c|c|}
\hline \multicolumn{4}{|c|}{ Duple } & \multicolumn{3}{|c|}{ Triple } \\
\hline Song 1 & long & \multicolumn{2}{|c|}{$\begin{array}{l}\text { Mdifs unitary } \\
\text { equivalent }\end{array}$} & Poetic meters & $\begin{array}{l}\text { Motifs unitary } \\
\text { equivalent }\end{array}$ & Poetic meters \\
\hline Song 2 & Short & J & $\delta$ & Dactylic & $\delta \bar{\delta} \delta$. & Anapestic \\
\hline Song 3 & Short & . & $\delta$ & Anapestic & & Limbic \\
\hline Song 4 & Short & ס & $\delta$ & Iambic & & Dactylic \\
\hline Song 5 & short & d & $\delta$ & Limbic & & Amphibraclic \\
\hline & & & & Spondaic & & Spondaic \\
\hline
\end{tabular}




\subsubsection{Texture}

The instrumental playing is highly polyphonic with the vocal music; it is quite different that most songs fall under the category of monody. That is both soloist and the response often form one musical phrase e.g. vocalist and chorus fitting into one melodic line.

\section{The Influence of Music in the Society}

Paul Greston (1981) states that music as a language has been acknowledged and consciously and unconsciously used by composers since A.D 1400. It is used to show preeminently, as language of emotions and moods. As with cultural language, music language it to communicate ideas, describe sciences, relates stories, discuss philosophical ideas etc. on the other hand, music language without benefit of text can express and communicate only emotions and moods. That is the only different between verbal language culture and music. For example, language has letters and symbols for sound, while music has notes and symbols for tone or musical sounds, further, language can be juxtaposed with language dialects, folk songs and popular ballads etc. the voice and inflection govern to a great extent semantics or meaning, similarly, dynamics, nuances, and inflection govern expression in music (Rosicrucion Digest, 1981).

Mendelssolin (1980-1947) $8^{\text {th }}$ century musician stated that the thoughts which I love are not too definite to be put into words, but on the contrary, too definite. In other words, the sound produced by music is so precise that there is no one word that can express it. Hat is so say that, a single chord can arouse a feeling which no word or synonym or a combination of synonyms can effectively describe. The initial word that may some to one's mind might be said, then may follow such words as melancholy doleful, pathetic, mournful, gloomy, tragic, disconsolation and multidinous other word.

\section{Conclusion}

Many years ago, it was possible in most parts of Nigeria to listen to performance of various types of traditional music almost every night. This explains the importance of indigenous traditional music of our land. Therefore, while is impossible for any culture to exist in a vacuum, it should not exist in an atmosphere where it becomes diffused to the point of extinction. Youths should be encouraged to participate in cultural association like cultural dance for them to learn culture and as well as engage themselves.

\section{References}

Echezona, W. W. C. (1965). Ibo Musical Instruments. Nigeria Magazine No. 84.

Ekwerou, B. C. (2003). Traditional Conservation Methods as a Way of Life in Igbo Communities (International Symposium Harvesting and Sharing Indigenous Knowledge in Africa Owere. 340-357.

Eze, K. (2012). Orba Transsmittion to the Researchers as Secretary of Ikorodo Orba Group.

Fay, F., \& Musser, W. I. (1960). All About Music-Rockville Centre. New York: Etmas Publishing Company.

Omibiyi, M. (1977) Nigerian Musical Instruments in Nigeria Magazine.

Ossai, C. J. (2007). Ikorodo, Our Music, Our Philosophy. State Independence Day Celebration Michael Opkala Square When the Enugu Ikorodo Orba Was Invited for a Competition Organized by Sullivan Chime "the Governor" of Enugu State by Department of Culture and Tourism.

Oxford and Longman Dictionary, New Edition.

Peggy, H. (1962). Dance and Drama in the North, Nigeria. 